\title{
Sodium-stimulated transport of glutamate by Thermus thermophilus strain B
}

\author{
Graham J. Holtom, ${ }^{1} \uparrow$ Richard J. Sharp ${ }^{2}$ and Ralph A. D. Williams ${ }^{1 *}$ \\ ${ }^{1}$ Biochemistry Department, London Hospital Medical College, London EI $2 A D$, UK \\ ${ }^{2}$ Biotechnology Division, Centre for Applied Microbiology Research, Porton Down, Salisbury, Wiltshire SP4 ORJ, UK
}

(Received 26 February 1993; accepted 13 May 1993)

\begin{abstract}
Thermus thermophilus B is one of the many Thermus strains able to utilize glutamate as a sole source of carbon. Sodium is an obligate requirement for glutamate transport by washed whole cells, but the affinity for sodium $\left(K_{\mathrm{m}}=23 \mathrm{mM}\right)$ is low. At $\mathrm{pH} 7.6$, uptake of glutamate is rapid in 50 mM-sodium at $65{ }^{\circ} \mathrm{C}$ and obeys saturation kinetics with an apparent $K_{\mathrm{m}}$ of $0.23 \mu \mathrm{M}$-glutamate and a $V_{\max }$ of $12 \mathrm{nmol}$ glutamate $\min ^{-1}$ (mg protein) ${ }^{-1}$. The transport system is insensitive to osmotic shock and is specific for glutamate, with both the $\mathrm{L}$ - and $\mathrm{D}$-isomers being transported. Uptake is very sensitive to inhibitors that collapse the membrane potential $(\Delta \psi)$ or the chemical gradient of sodium ions $(\Delta p \mathrm{Na})$, but a transmembrane $\mathrm{pH}$ gradient $(\Delta \mathrm{pH})$ plays no role in the transport of glutamate. These results are therefore consistent with a membrane sodium/glutamate symport system.
\end{abstract}

\section{Introduction}

Thermus species are thermophilic, aerobic, Gram-negative heterotrophs. Yellow isolates are similar to the type strain (YT1) of Thermus aquaticus (Brock \& Freeze, 1969 ), and grow optimally at approximately $70^{\circ} \mathrm{C}$. Red pigmented strains of Thermus ruber (Loginova \& Egorova, 1975) have lower temperature optima close to $60^{\circ} \mathrm{C}$. Many strains of both types have been isolated from natural (Hudson et al., 1989; Munster et al., 1986; Pask-Hughes \& Williams, 1977; Santos et al., 1989) and man-made (Brock \& Boylen, 1973; Pask-Hughes \& Williams, 1975) thermal sources worldwide. Yellow pigmented Thermus isolates are heterogeneous, with several genospecies detected by DNA:DNA hybridization (Williams, 1989). One homology group corresponds to 'Thermus thermophilus' (Oshima \& Imahori, 1974). Thermus strain B (NCIB 11247), the subject of the present study, has a high DNA:DNA homology with strain HB8.

Studies of the physiology and growth of these organisms (Bergquist et al., 1987; McKay et al., 1982; Wiegel \& Ljungdahl, 1984) have paid little attention to the transport of nutrients across the membrane. Some

* Author for correspondence. Present address: Biochemistry Department, Queen Mary \& Westfield College, Mile End Road, London E1 4NS, UK. Tel. (071) 9826337 ; fax (081) $983053 \mathrm{I}$.

\$ Present address: AEA Technology, 353, Harwell, Didcot, Oxfordshire OX11 ORA, UK. active transport processes in Gram-negative bacteria are sensitive to osmotic shock, which disables transport by releasing the substrate-binding proteins from the periplasmic space, but causes no loss in viability. The protein that specifically binds a substrate, often with high affinity, may be isolated from the 'shock' fluid. This periplasmic binding protein, complexed with its substrate, interacts with translocation proteins that hydrolyse ATP at the cytoplasmic surface of the membrane (Ames, 1986). A second class of transport processes often have lower affinities for their substrates and are insensitive to osmotic shock. They are commonly energized by a proton (or other ion) motive force, and substrate uptake occurs in symport (cotransport) with the ion (Kaback, 1986, 1990; Maloy, 1990) in Gram-positive and Gramnegative micro-organisms. The proton motive force (pmf, $\Delta \mu_{\mathrm{H}^{+}}$) is generated by proton pumping across a membrane that is otherwise impermeable to protons, and comprises an electrochemical gradient ( $\Delta \psi$ positive to the outside) and a $\mathrm{pH}$ gradient $(\Delta \mathrm{pH}$ acidic to the outside) that are related by the equation

$$
\operatorname{pmf}=\Delta \psi-Z \Delta \mathrm{pH}\left(Z=67 \text { at } 60^{\circ} \mathrm{C}\right)
$$

Cells may form an energetically useful transmembrane gradient of other cations such as sodium, when $\Delta \mu_{\mathrm{Na}^{+}}$ substitutes for $\Delta \mu_{\mathrm{H}^{+}}$. Transport systems are known to depend on sodium in enteric bacteria (Caimey et al., 1984; Chen \& Russell, 1989; Fujimura et al., 1983; Russell et al., 1988), some thermophiles (De Vrij et al., 1989, 1990; Speelmans et al., 1989), and in alkaliphilic 
and marine micro-organisms for which sodium plays a special role (Dimroth, 1987; Maloy, 1990; Krulwich \& Ivey, 1990). Sodium dependent transport systems may also involve special sodium extrusion systems. For alkaliphiles sodium/proton antiporters serve to acidify the cytosol and generate inwardly directed sodium motive force (Krulwich \& Guffanti, 1989). Many halophiles have a respiration-dependent primary sodium pump that provides energy for substrate uptake (Unemoto \& Hayashi, 1989; Unemoto et al., 1990). Halotolerant bacteria have several mechanisms for the extrusion of sodium ions (De Vrij et al., 1990). This paper, which is part of a study of the growth physiology of Thermus (Holtom, 1991), describes a high affinity glutamate transport system in Thermus strain B that is insensitive to osmotic shock and dependent on sodium ions.

\section{Methods}

Growth and maintenance. Thermus strain B was isolated in Iceland (Williams, 1975) and since maintained freeze-dried. In the short term, working stock suspensions were stored frozen. The growth medium (TYE) used for culturing Thermus contained $0-3 \%(\mathrm{w} / \mathrm{v})$ tryptone and $0.1 \%(\mathrm{w} / \mathrm{v})$ yeast extract with $10 \%(\mathrm{v} / \mathrm{v})$ of $\times 10$ Castenholz mineral salts solution (Ramaley \& Hixson, 1970). Cells were cultured at $60^{\circ} \mathrm{C}$ in an orbital incubator and aerated by shaking at 200 r.p.m. The culture was stored on plates of TYE medium containing $2 \%(\mathrm{w} / \mathrm{v})$ agar at $4{ }^{\circ} \mathrm{C}$ and subcultured every 2 weeks. Viable counts were performed using a $0.1 \mathrm{ml}$ spread plate technique using sterile TYE broth as a diluent.

Glutamate uptake assays. Mid exponential phase cells, with an $\mathrm{OD}_{600}$ of approximately 1.8 , were harvested by centrifugation for $2 \mathrm{~min}$ at $7000 \mathrm{~g}$ in an MSE Microcentaur at room temperature. The cells were washed once in the assay buffer followed by centrifuging for $1 \mathrm{~min}$ at $7000 \mathrm{~g}$ at room temperature and resuspended at concentrations of $3-5 \mu \mathrm{g}$ cell protein $\mathrm{ml}^{-1}$. These dilute suspensions were necessary to investigate the high affinity glutamate transport system, and were either used immediately, or stored at $4{ }^{\circ} \mathrm{C}$ for $1-4 \mathrm{~h}$ before use. Such storage made no difference to the rate of glutamate transport. Aliquots of $9 \mathrm{ml}$ of cell suspension were pre-incubated for $10 \mathrm{~min}$ at the assay temperature in a New Brunswick G76D shaking water-bath. The uptake of glutamate was usually initiated by addition of $1 \mathrm{ml} 1 \mu \mathrm{M}-\mathrm{L}-$ [U- ${ }^{14} \mathrm{C}$ glutamate $\left[270 \mathrm{mCi} \mathrm{mmol}^{-1}\right.$ (about $10 \mathrm{GBq} \mathrm{mmol}^{-1}$ ), the highest specific activity available], to a final concentration of $0.1 \mu \mathrm{M}$. Samples ( $1 \mathrm{ml}$ containing $0.025 \mu \mathrm{Ci}$ equivalent to 60000 d.p.m.) were taken at $15 \mathrm{~s}$ intervals and filtered rapidly through cellulose nitrate filters (Whatman), $0.45 \mu \mathrm{m}$ pore size. The filters were then washed with $2 \mathrm{ml}$ of cold sterile assay buffer and dried at $80^{\circ} \mathrm{C}$ for $1 \mathrm{~h}$. PCS scintillant (Amersham) was added $(3.5 \mathrm{ml})$ to the dried filters and the radioactivity counted in an LKB 1215 liquid scintillation counter. Typical count rates for filters were about 300 c.p.m. against a background of 30 c.p.m. Where ionophores were used, these were added (concentrations in Table 1) to the incubation mixture $2 \mathrm{~min}$ before substrate addition.

Control bacterial suspensions were boiled for $15 \mathrm{~min}$ and used to test the non-specific binding of glutamate to the cells and filters. Boiled controls were used because in unboiled control suspensions glutamate transport occurred, even after several hours in the absence of an exogenous energy source. These control counts were subtracted from experimental results. Lines of best fit were calculated from data points using linear regression analysis, and the kinetic constants were calculated using the EZ-FIT kinetics software package (Perella, 1988). The graphs provided are illustrative and were not used to calculate kinetic constants.

Osmotic shock and chloroform treatment. These treatments were used to attempt the selective release of periplasmic proteins (Ames $e t$ al., 1984; Venegas et al., 1980).

Treatment of protein and equilibrium dialysis. For glutamate binding dialysis tubing was boiled in $2 \%(\mathrm{w} / \mathrm{v})$ sodium bicarbonate and in $1 \mathrm{mM}$-EDTA, stored in $1 \mathrm{~mm}$-EDTA at $4^{\circ} \mathrm{C}$, and rinsed well in demineralized water. Cellular proteins $\left(0.1-0.5 \mathrm{mg} \mathrm{ml}^{-1}\right)$ were reversibly denatured by dialysing against 100 vols $50 \mathrm{~mm}-\mathrm{Tris} / \mathrm{HCl}, \mathrm{pH} 7.8$, $5 \mathrm{~mm}$-EDTA, $5 \mathrm{~mm}$-DTT and $6 \mathrm{~m}$-guanidine hydrochloride, and renatured by dialysis against $3 \times 100$ vols $50 \mathrm{mM}-\mathrm{Tris} / \mathrm{HCl}, \mathrm{pH} 7.8,5 \mathrm{~mm}-$ EDTA and 2 mM-DTT. Samples of protein were assayed for glutamate binding by equilibrium dialysis in a series of dialysis bags immersed in $5 \mathrm{ml}$ bottles each containing $25 \mathrm{pmol} \mathrm{L}-\left[\mathrm{U}_{-}{ }^{14} \mathrm{C}\right] \mathrm{glutamic}$ acid in $2 \mathrm{ml}$ of the same buffer. Some dialyses also contained $50 \mathrm{~mm}-\mathrm{NaCl}$. After overnight incubation at $60^{\circ} \mathrm{C}, 100 \mu 1$ aliquots from inside and outside each dialysis bag were mixed with $3.5 \mathrm{ml}$ of PCS scintillant and counted in an LKB 1215 liquid scintillation counter.

Protein estimation. Protein concentrations were measured by the Coomassie dye binding method (Bradford, 1976) using Pierce reagent.

Materials. L-[U- $\left.{ }^{14} \mathrm{C}\right]$ Glutamic acid was from Amersham and [methyl$\left.{ }^{3} \mathrm{H}\right]$ triphenylphosphonium iodide was from New England Nuclear. All other chemicals were of the highest purity obtainable.

\section{Results}

\section{Cation specificity}

No radioactivity above background was detected in cells and therefore no glutamate uptake took place in Thermus strain B in 50 mM-potassium phosphate buffer at $\mathrm{pH} 7.6$ and $55^{\circ} \mathrm{C}$, unless sodium ions were added (Fig. 1). Rates of glutamate uptake at $55^{\circ} \mathrm{C}$ by cells stored at $4{ }^{\circ} \mathrm{C}$ in

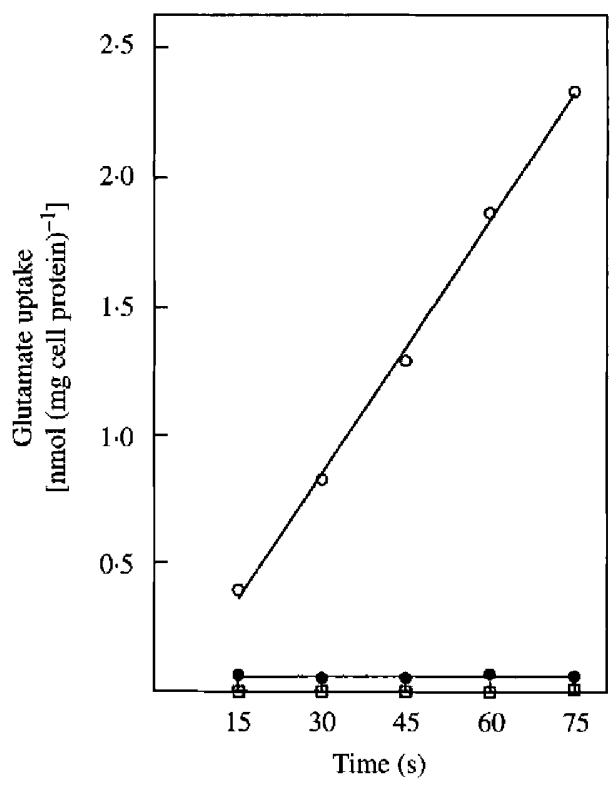

Fig. 1. Effect of $50 \mathrm{~mm}$-sodium $(\mathrm{O})$ or -lithium (๑) chloride or no addition $(\square)$ on the transport of glutamate by Thermus thermophilus strain $\mathrm{B}$ at $\mathrm{pH} 7.6$ and $55^{\circ} \mathrm{C}$ in $50 \mathrm{~mm}$-potassium phosphate buffer. 


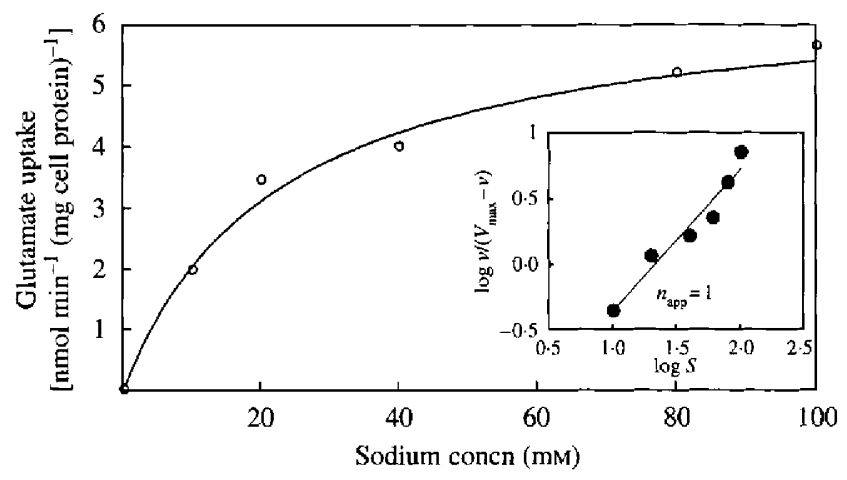

Fig. 2. Effect of sodium concentration on the rate of glutamate transport by Thermus thermophilus strain B in 50 mm-potassium phosphate at $\mathrm{pH} 7.6$ and $65^{\circ} \mathrm{C}$. A Hill plot of the same data is inset. In triplicate experiments the extremes were $+/-$ the following per cent of the means; $10 \mathrm{mM}, 8.5 \% ; 20 \mathrm{~mm}, 3.6 \% ; 40 \mathrm{~mm}, 1.8 \% ; 60 \mathrm{~mm}, 4.6 \%$; $80 \mathrm{~mm}, 6.5 \%$; and $100 \mathrm{~mm} 7.6 \%$.
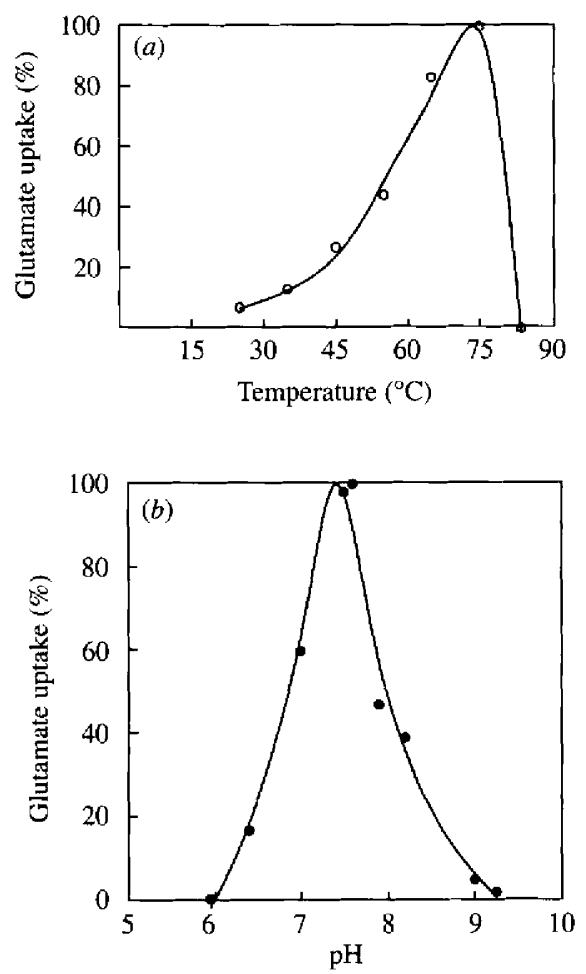

Fig. 3. Effect of temperature ( $a$ at $\mathrm{pH} 7.6)$ and $\mathrm{pH}\left(b\right.$ at $\left.65^{\circ} \mathrm{C}\right)$ on the initial rate of glutamate uptake by Thermus thermophilus strain B in $50 \mathrm{~mm}$-phosphate buffer containing $50 \mathrm{~mm}$-sodium chloride. The mean and range of three determinations was $82(81-83)$ at $65^{\circ} \mathrm{C}$ and $45(40-52)$ at $55^{\circ} \mathrm{C}(a)$, and $60(58-62)$ at $\mathrm{pH} 7.0$ and $39(36-41)$ at pH $8.25(b)$.

this buffer were constant for several hours. No glutamate transport occurred when $50 \mathrm{~mm}$-lithium replaced sodium. Similar results with the cationic buffers Tris, TES and HEPES in place of potassium phosphate showed that glutamate transport did not require potassium.

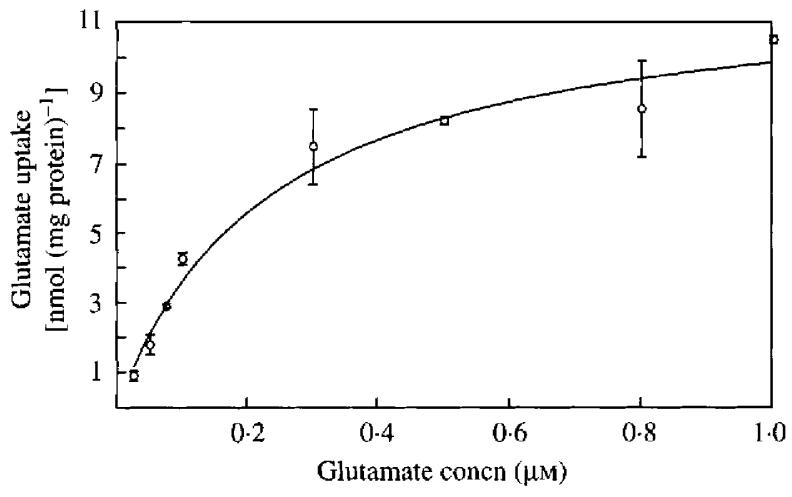

Fig. 4. Effect of increasing glutamate concentration on the rate of glutamate uptake by Thermus thermophilus strain B at $65^{\circ} \mathrm{C}$ in $50 \mathrm{mM}$ phosphate buffer $\mathrm{pH} 7.6$ and $50 \mathrm{~mm}$-sodium chloride. Results are means and ranges for triplicate estimations. The $K_{\mathrm{m}}$ and $V_{\max }$ were calculated by EZ-FIT, not from this graph.

Cells suspended in $50 \mathrm{~mm}$-potassium phosphate buffer $\mathrm{pH} 7.6$ were diluted into similar buffers between $\mathrm{pH} 6.0$ and 8.0 and containing $0.1 \mu \mathrm{M}$ radiolabelled glutamate at the highest possible specific activity at $55^{\circ} \mathrm{C}$. The different degrees of $\Delta \mathrm{pH}$ so generated did not drive glutamate uptake unless sodium was added, indicating that $\Delta \mathrm{pH}$ plays no role under these conditions. Increasing the sodium concentration in the incubation medium at $\mathrm{pH} 7.6$ caused a progressive increase in the rate of glutamate uptake (Fig. 2). The apparent $K_{\mathrm{m}}$ for sodium was approximately $23 \mathrm{mM}$, which is less than half the sodium concentration routinely used in buffers in these experiments. The Hill plot for this data (Fig. 2 inset) had a slope of one.

\section{Kinetics of glutamate transport}

The optimum temperature and $\mathrm{pH}$ for glutamate uptake in strain $\mathrm{B}$ were $75^{\circ} \mathrm{C}$ and $\mathrm{pH} 7.6$ respectively (Fig. 3). At $75^{\circ} \mathrm{C}$, however, the assay buffer evaporated rapidly and assays were therefore routinely performed at $65^{\circ} \mathrm{C}$ at which temperature the rate was $90-95 \%$ of that at $75^{\circ} \mathrm{C}$. Under these conditions, the kinetic parameters of transport were determined from initial rates of uptake in $50 \mathrm{~mm}$-potassium phosphate buffer and $50 \mathrm{~mm}$-sodium, at glutamate concentrations between $0.025 \mu \mathrm{M}$ and $1 \mu \mathrm{M}$ at high specific activities (Fig. 4). The apparent $K_{\mathrm{m}}$ for transport was $0.23 \mu \mathrm{M}$-glutamate and the $V_{\max } 12 \mathrm{nmol}$ glutamate $\min ^{-1}$ (mg protein) ${ }^{-1}$.

\section{Effect of osmotic shock}

An osmotic shock procedure (Venegas et al., 1980) was carried out three times on cells of Thermus strain B capable of active transport. The first shock resulted in no 
loss of viability or transport activity. The second and third shocks reduced viability by $63 \%$ and over $99 \%$, and reduced glutamate transport by $5 \%$ and $71 \%$ respectively. No glutamate binding protein was detected by equilibrium dialysis of any of the three shock fluids, whether the proteins were reversibly denatured or untreated, and in the presence or absence of $\mathrm{NaCl}$. The attempted release of periplasmic binding protein using chloroform (Ames et al., 1984) resulted in immediate and complete loss of viability and transport activity, but again no glutamate binding proteins were detected by equilibrium dialysis.

\section{Effect of inhibitors}

Ionophores that collapse the proton motive force, carbonyl cyanide chlorophenylhydrazone (CCCP) and 2,4-dinitrophenol (2,4-DNP) were very inhibitory to glutamate uptake in Thermus strain B (Table 1) in $50 \mathrm{~mm}$-phosphate buffer pH 7.6 containing $50 \mathrm{~mm}$ sodium ions at $65^{\circ} \mathrm{C}$. This might be due to a collapse in $\Delta \psi, \Delta \mathrm{pH}$ or both, but other evidence cited above suggests that $\Delta \mathrm{pH}$ is unimportant. The sensitivity of glutamate uptake to thiocyanate and valinomycin (Table 1 ), both of which specifically collapse $\Delta \psi$ under the assay conditions, demonstrates the importance of $\Delta \psi$ and implies that glutamate uptake is electrogenic.

These observations, and the obligate requirement of sodium for glutamate transport, imply that transport may be energized by a sodium motive force, and therefore a chemical gradient of sodium ions $(\Delta p \mathrm{Na})$ would be

Table 1. Effect of protonophores, collapsers of $\Delta \psi$, monensin and nigericin on glutamate transport by Thermus strain B

The concentrations of inhibitor cited are the minimum concentrations required to bring about the described degree of inhibition. The inhibitors were added $2 \mathrm{~min}$ before the addition of $\mathrm{L}-[\mathrm{U}-$ ${ }^{14} \mathrm{Clglutamate}$ to a final concentration of $0.1 \mu \mathrm{M}$, in buffer containing 50 mM-sodium ions at $\mathrm{pH} 7.6$ and $65^{\circ} \mathrm{C}$.

\begin{tabular}{|c|c|c|c|}
\hline Compound & Concn & $\begin{array}{c}\text { Buffer } \\
(50 \mathrm{~mm})\end{array}$ & $\begin{array}{c}\text { Inhibition } \\
(\%)\end{array}$ \\
\hline Control & & Phosphate & 0 \\
\hline 2,4-DNP & $5 \mathrm{mM}$ & Phosphate & 91 \\
\hline $\mathrm{CCCP}$ & $50 \mu \mathrm{M}$ & Phosphate & 96 \\
\hline Valinomycin & $0.7 \mathrm{nM}$ & Phosphate & 99 \\
\hline $\mathrm{NaSCN}$ & $10 \mathrm{~mm}$ & Phosphate & 97 \\
\hline Control & & Phosphate & 0 \\
\hline Monensin & $0.03 \mu \mathrm{M}$ & Phosphate & 98 \\
\hline Nigericin & $0.4 \mu \mathrm{M}$ & Phosphate & 94 \\
\hline Control & & Tris & 0 \\
\hline Monensin & $0.03 \mu \mathrm{M}$ & Tris & 99 \\
\hline Nigericin & $1 \mu \mathrm{M}$ & Tris & 95 \\
\hline
\end{tabular}

expected to be significant. This gradient would be collapsed by the sodium/proton antiporter monensin, which preferentially exchanges one sodium ion for one proton and has no effect on $\Delta \psi$. Monensin inhibited the transport of glutamate by Thermus in both Tris and phosphate buffers (Table 1). Nigericin, a nonelectrogenic antiporter that preferentially exchanges protons for potassium (or sodium with decreased affinity) was also inhibitory and mimicked monensin in Tris buffer without potassium, but monensin was 30 times as effective as nigericin. In the presence of potassium the nigericin concentration required to produce a similar degree of inhibition was halved. Under these conditions protons are exchanged for potassium ions. As neither potassium ions nor $\Delta \mathrm{pH}$ is important for glutamate transport internal cellular $\mathrm{pH}$ may be significant.

\section{Specificity}

The specificity of the transport system was assessed from the extent of inhibition of $\mathrm{L}-\left[\mathrm{U}-{ }^{14} \mathrm{C}\right] \mathrm{glutamate}$ uptake by a 30-fold excess of other amino acids (Table 2). Twenty of the compounds tested inhibited glutamate transport less than $18 \%$. Only glutamine, leucine and valine inhibited more than the variation in control values. Increase in concentration of these three amino acids to $300 \times$ the L-glutamate concentration resulted in no further inhibition. The presence of either $\alpha$-oxoglutarate or $L-\alpha$-aminopentanoic acid also caused no inhibition, indicating that an amino and two carboxylic acid groups are essential structural features of an inhibitor. The transport of radiolabelled L-glutamate was reduced to

\section{Table 2. Effect of amino acids on the uptake of glutamate by Thermus strain $B$}

Percentage inhibition of the uptake of $\mathrm{L}-\left[\mathrm{U}_{-}{ }^{14} \mathrm{C}\right]$ glutamate $(0 \cdot 1 \mu \mathrm{M})$ by the presence of $3 \mu \mathrm{M}$ unlabelled test substance. L-Serine, Lalanine and L-histidine caused $2-4 \%$ inhibition; L-glycine, Lproline, L-methionine, L-tryptophan, L-phenylalanine, L-tyrosine, L-cysteine, L-lysine, L-threonine, L-arginine and 2-oxoglutarate all gave no inhibition.

\begin{tabular}{|c|c|}
\hline $\begin{array}{c}\text { Test } \\
\text { substance }\end{array}$ & $\begin{array}{c}\text { Reduction in } \\
\text { uptake of } \\
\text { L-glutamate } \\
(\%)\end{array}$ \\
\hline L-Glutamate & 89 \\
\hline D-Glutamate & 87 \\
\hline L-Glutamine & 18 \\
\hline L-Leucine & 18 \\
\hline L-Valine & 13 \\
\hline L- $\alpha$-Aminobutyrate & 7 \\
\hline L-Aspartate & 6 \\
\hline L-Asparagine & 6 \\
\hline L-Isoleucine & 6 \\
\hline$L$ - $\alpha$-Aminopentanoate & 5 \\
\hline
\end{tabular}


a similar extent by both unlabelled isomers. Therefore this system transports both the L- and D-isomers of glutamate.

\section{Discussion}

Many strains of the genus Thermus are able to utilize glutamate as the sole source of carbon (Hudson et al., 1989; Munster et al., 1986; Pask-Hughes \& Williams, 1977). Transport of glutamate was studied with whole cells in this first study of Thermus. Uptake is rapid at $\mathrm{pH} 7.6$ and increases with temperature up to $75^{\circ} \mathrm{C}$, but is negligible at $83^{\circ} \mathrm{C}$. This correlates well with the maximum temperature of the spring from which the strain was isolated $\left(82^{\circ} \mathrm{C}\right.$; Williams, 1975$)$ and indicates that destabilization of the membrane may limit growth at high temperatures. The transport system described here is highly specific for glutamate of either isomer. Uptake of the L-isomer occurs with high affinity $\left(K_{\mathrm{m}}=0.23 \mu \mathrm{M}\right.$ glutamate) and a maximum velocity of around $12 \mathrm{nmol}$ glutamate $\min ^{-1}$ (mg protein) ${ }^{-1}$. Osmotic shock has no effect on transport which, in Gram-negative microorganisms, is commonly associated with a periplasmic binding protein (Ames, 1986) that is released by such shocks.

Uptake is abolished by heating and by chemical inhibitors. This precludes the possibility of transport by passive diffusion. Sodium is obligatory for transport at $\mathrm{pH} 7.6$ and no counts above background are taken up if sodium is omitted. The artificial imposition of a $\Delta \mathrm{pH}$ at $\mathrm{pH} 6.0$ is insufficient to drive transport in the absence of sodium, and does not stimulate transport in the presence of sodium. The Thermus transport system $\left(K_{\mathrm{m}}=23 \mathrm{~mm}\right)$ resembles that of Streptococcus bovis in its low affinity for sodium $\left(K_{\mathrm{m}}=30 \mathrm{~mm}\right)$, which prevented the direct demonstration of simultaneous sodium and amino acid uptake (Russell et al., 1988). Direct sodium/glutamate cotransport was not detectable using either sodium ion selective electrodes or atomic absorption spectroscopy. These techniques are not sufficiently sensitive to detect changes of nmol quantities of ion against a background of $50 \mathrm{~mm}$-sodium. The use of ${ }^{22} \mathrm{Na}$ was discounted because the specific activities available were not high enough to estimate sodium uptake at low sodium concentrations. In hot springs in Yellowstone National Park (Brock, 1978) and Iceland (Stainthorpe, 1986) concentrations of sodium are 2-20 mM so the low affinity is surprising and means that in the natural environment such a system may operate sub-optimally.

Glutamate uptake is sensitive to collapse of both the electrochemical gradient $(\Delta \psi)$ and the chemical gradient of sodium ions $(\Delta p \mathrm{Na})$, but proceeds following the artificial imposition of $\Delta p \mathrm{Na}$ and is inhibited by compounds that collapse it. Furthermore, transport of glutamate is inactive at $\mathrm{pH} 6.0$ (when the proton motive force comprises a large $\Delta \mathrm{pH}$ with little $\Delta \psi$ ) although the strain can grow at this $\mathrm{pH}$ on complex media (Holtom, 1991). This provides more evidence that $\Delta \mathrm{pH}$ plays no role and that $\Delta \psi$ is essential. The dependence of transport on $\Delta \psi$ implies that uptake is driven electrogenically, and predicts a net movement of positive charge. Glutamic acid has one net negative charge throughout the physiological $\mathrm{pH}$ range for transport, and therefore a net movement of positive charge requires at least two cations to be transported in symport with one glutamate. Despite this predicted stoichiometry, the effect of sodium ion concentrations upon transport obeys Michaelis-Menten first order kinetics, and a Hill plot of the data has a slope of one (Fig. 2). However, these results reflect overall transport activity and under such circumstances, the stoichiometry cannot be estimated.

A role for internal cell $\mathrm{pH}$ in the control of glutamate transport is suggested by the results with the ionophore nigericin. The internal $\mathrm{pH}$ affects some transport systems in other bacteria, but has not been reported for other sodium/solute symporters (Abee et al. 1989; Noji et al., 1988). This effect is most likely due to the physiological consequences of altering the $\mathrm{pH}$ rather than to the alteration of $\Delta \mathrm{pH}$.

It has been suggested that the involvement of sodium in bacterial bioenergetics and membrane transport is relatively recent in evolution, with protons being the primitive currency for membrane energy transduction (Dimroth, 1987; Maloy, 1990). This argument suggests that sodium coupled symporters with differing cation specificities may represent stages in the evolution from proton to sodium driven energetics. However, on the basis of $16 \mathrm{~S}$ ribosomal RNA sequencing $T$. thermophilus is a particularly ancient organism, being on the deepest branch on the eubacterial phylogenetic tree after the genus Thermotoga (Hartmann et al., 1989). Since glutamate transport requires, and is driven by, sodium in Thermus strain B, it therefore seems that a role for sodium in bioenergetics may have evolved earlier than has been supposed.

This research was supported by CASE award grant 87506219 from the Science and Engineering Research Council, and was submitted by G. J. Holtom in partial fulfilment of the requirement for the degree of $\mathrm{PhD}$ of London University.

\section{References}

Abee, T., Van de Wal., F.-J., Hellingwerf, K. J. \& Konings, W. N. (1989). Binding-protein-dependent alanine transport in Rhodobacter sphaeroides is regulated by the internal pH. Journal of Bacteriology $171,5148-5154$.

AMES, G. F.-L. (1986), Bacterial periplasmic transport systems: structure, mechanism and evolution. Annual Review of Biochemistry 55, $397-425$. 
Ames, G. F.-L., Prody, C. \& Kustu, S. (1984). Simple rapid and quantitative release of periplasmic proteins by chloroform. Journal of Bacteriology 160, 1181-1183.

BRADFORD, M. M. (1976). A rapid and sensitive method for the quantitation of microgram quantities of protein utilizing the principle of protein-dye binding. Analytical Biochemistry 72, 248-254.

Bergouist, P. L., Love, D. R., Croft, J. E., Streiff, M. B., Daniel, R. M. \& MorGaN, W. H. (1987). Genetics and potential biotechnological applications of thermophilic and extremely thermophilic microorganisms. Biotechnology and Genetic Engineering Reviews 5, 199-244.

Brock, T. D. (1978). Thermophilic Microorganisms and Life at High Temperatures, pp. 30-33, New York: Springer-Verlag.

Brock, T. D. \& Boylen, L. K. (1973). Presence of thermophilic bacteria in laundry and domestic hot water heaters. Applied Microbiology 17, 72-76.

BROCK, T. D. \& FrEEZE, H. (1969). Thermus aquaticus gen. n. and sp.n., a non-sporulating extreme thermophile. Journal of Bacteriology 48 , 289-297.

Cairntey, S., Higgins, C. F. \& Booth, I. R. (1984). Proline uptake through the major transport system of Salmonella typhimurium is coupled to sodium ions. Journal of Bacteriology 160, 22-27.

Chen, G. \& Russell, J. B. (1989). Sodium-dependent transport of branched-chain amino acids by a monensin sensitive ruminal Peptostreptococcus. Applied and Environmental Microbiology 55, 2658-2663.

De Vru, W., Bulthuis, R. A., van Iwaarden, P. R. \& Konings, W. N. (1989). Mechanism of L-glutamate transport in membrane vesicles from Bacillus stearothermophilus. Journal of Bacteriology $171,1118-1125$

De VriJ, W., Speflmans, G., Heyne, R. I. R. \& Konings, W. N (1990). Energy transduction and amino acid transport in thermophilic aerobic and fermentative bacteria. FEMS Microbiology Reviews 75, 183-200.

DimRorH, P. (1987). Sodium ion transport decarboxylases and other aspects of sodium ion cycling in bacteria. Microbiological Reviews $\mathbf{5 1}$, $320-340$

Fujimura, T., Yamato, I. \& ANRaku, Y. (1983). Mechanism of glutamate transport in Escherichia coli B: kinetics of glutamate transport driven by artificially imposed proton and sodium ion gradients across the cytoplasmic membrane. Biochemistry 22, $1959-1965$

Hartmann, R. K., Walters, J., Kruger, B., Schultze, S., Specht, T. \& ERdmanN, V.A. (1989). Does Thermus represent another deep eubacterial branching? Systematic and Applied Microbiology 11 243-249.

HоLтом, G. J. (1991). The physiology and biochemistry of glutamate transport and utilisation in the genus Thermus. $\mathrm{PhD}$ Thesis, University of London.

Hudson, J. A., Morgan, H. W. \& Daniel, R. M. (1989). Numerical classification of Thermus isolates from globally distributed hot springs. Systematic and Applied Microbiology 11, 250-256.

KABACK, H. R. (1986). Active transport in E. coli passage to permease Annual Review of Biophysics and Biophysical Chemistry 15, 279-319.

KABACK, H. R. (1990). Active transport: membrane vesicles, bioenergetics, molecules and mechanisms. In The Bacteria, vol. 12, Bacterial Energetics, pp. 151-202. Edited by T. A. Krulwich. New York: Academic Press.

KRULWICH, T. A. \& IveY, D. A. (1990). Bioenergetics in extreme environments. In The Bacteria, vol. 12, Bacterial Energetics, pp. 417-447, Edited by T. A. Krulwich. New York: Academic Press.

KRULwich, T. A. \& GuFfanti, A. A. (1989). The $\mathrm{Na}^{+}$cycle of extreme alkalophiles: a secondary $\mathrm{Na}^{+} / \mathrm{H}^{+}$antiporter and $\mathrm{Na}^{+}$/solute symporters. Journal of Bioenergetics and Biomembranes 21, 663-678.
Loginova, L. G. \& Egorova, L. A. (1975). An obligately thermophilic bacterium Thermus ruber from hot springs in Kamchatka. Mikrobiologiya 44, 661-665.

MaLoY, S. R. (1990). Sodium-coupled cotransport. In The Bacteria vol. 12, Bacterial Energetics, pp. 203-224. Edited by T. A. Krulwich. New York: Academic Press.

MCKay, A., QUILTER, J. \& JoNes, C. W. (1982). Energy conservation in the extreme thermophile Thermus thermophilus HB8. Archives of Microbiology 131, 43-50.

Munster, M. J., Munster, A. P., Woodrow, J. R. \& Sharp, R. J. (1986). Isolation and preliminary taxonomic studies of Thermus strains isolated from Yellowstone National Park, USA. Journal of General Microbiology 132, 1677-1683.

NoJ, S., Sato, Y., Suzuki, R. \& Taniguchl, S. (1988). Effect of intracellular $\mathrm{pH}$ and potassium ions on a primary transport system for glutamate/aspartate in Streptococcus mutans. European Journal of Biochemistry 175, 491-495.

OsHIMA, T. \& IMAHORI, K. (1974). Description of Thermus thermophilus (Yoshida and Oshima) comb. nov., a non-sporulating thermophilic bacterium from a Japanese thermal spa. International Journal of Systematic Bacteriology 24, 102-112.

Pask-Hughes, R. \& Williams, R. A. D. (1975). Extremely thermophilic Gram negative bacteria from hot tap water. Journal of General Microbiology 88, 321-328.

Pask-Hughes, R. A. \& Williams, R. A. D. (1977). Yellow pigmented strains of Thermus spp. from Icelandic hot springs. Joumal of General Microbiology 102, 375-383.

Perella, F. W. (1988). EZ-FIT: a practical curve fitting microcomputer program for the analysis of enzyme kinetic data on IBMPC compatible computers. Analytical Biochemistry 174, 437-447.

RAMALEY, R. F. \& HIXson, J. (1970). Isolation of a non-pigmented, thermophilic bacterium similar to Thermus aquaticus. Joumal of Bacteriology 103, 527-528.

Russell, J. B., Strobel, H. J., Driessen, A. J. M. \& Koning, W. N. (1988). Sodium-dependent transport of neutral amino acids by whole cells and membrane vesicles of Streptococcus bonis, a rumina! bacterium. Journal of Bacteriology 170, 3531-3536.

Santos, M. N. A., Williams, R. A. D. \& DA Costa, M. S. (1989). Numerical taxonomy of Thermus isolates from hot springs in Portugal. Systematic and Applied Microbiology 12, 310-315.

Speelmans, G., De VRIJ, W. \& Konings, W. N. (1989). Characterization of amino acid transport in membrane vesicles from the thermophilic fermentative bacterium Clostridium fervidus. Journal of Bacteriology 171, 3788-3795.

STAINTHORPE, A. C. (1986). Thermophilic anaerobic cellulolytic bacteria from Icelandic hot springs. $\mathrm{PhD}$ thesis, University of London.

UNEMOTO, T. \& HAYASHI, M. (1989). Sodium transport NADHquinone reductase of a marine Vibrio alginolyticus. Journal of Bioenergetics and Biomembranes 21, 649-662.

Unemoto, T., TokUda, H. \& Hayashi, M. (1990). Primary sodium pumps and their significance in bacterial energetics. In The Bacteria, vol. 12, Bacterial Energetics, pp. 33-54. Edited by T. A. Krulwich. New York: Academic Press.

Venegas, A., Vicuna, R., Alonso, A., Valdez, F. \& Yudelevich, A. (1980). A rapid procedure for purifying a restriction endonuclease from Thermus thermophilus. FEBS Letters 109, 156-158.

WIEGEL, J. \& LJUNGDAHL, L. G. (1984). The importance of thermophilic bacteria in biotechnology. Critical Reviews of Biotechnology 3 , 39-107.

WiLliams, R. A. D. (1975). Caldoactive and thermophilic bacteria and their thermostable proteins. Science Progress 62, 373-393,

WII.IIAMS, R. A. D. (1989). Biochemical taxonomy of the genus Thermus. In Microbiology of Extreme Environments and its Potential for Biotechnology, pp. 82 97. Edited by M. S. da Costa, J. C. Duarte \& R. A. D. Williams. London: Elsevier. 